\title{
人の上り，下り時の負担からみた段差と斜路の比較 \\ EXAMINATION ON COMPARISON OF PHYSIOLOGICAL LOAD BETWEEN THE ONE STEP STAIR AND THE SLOPE IN GOING UP AND DOWN
}

\author{
小野英哲*
}

Hidenori $O N O$ \begin{abstract}
It is necessary to solve the problem of a level difference on floors from the viewpoint where it walks safely
and comfortably
in buildings.

The one step stair and the slope are general methods of solving a level difference greatly not large.

In this research, physiological loads in the one step stairs and the slopes were compared.

The results are as follows.

- The one step stairs and the slopes to give an equivalent physiological load, by the same height difference, exist in the range of level difference of $25 \mathrm{~cm}$ or less.

- When it is examined that the height of the one step stairs and the slopes length, physically handicapped passengers abilities should be assumed to be the main index.
\end{abstract}

Keywords: level difference, one step stair, slope, comparison, physiological load, physically handicapped passenger 高低差, 段差, 斜路, 比較, 生理的負担, 身体的弱者

\section{1. 序}

建築物内外には、同一階あるいは同一地面（以降、一括して同一 階と呼ぶ）において床あるいは路面（以降、一括して床と呼ぶ）に 高低差が存在する場合がある。

一方、高齢者を代表とする身体的弱者がさらに増加すると想定さ れる今後は、健常者をも含め、歩行者の負担の観点からできるだけ 高低差を設けないことが望ましいと考えるが、さまざまな理由から 高低差を設けざるを得ない場合も発生する。

同一階において、高低差がある床を歩行に供する代表的手段とし て、段差と斜路の設置があげられる。

ここで、段差と斜路のどちらが望ましいかに関してはさまざまな 観点から検討すべきであるが、いずれにせよ明確な指針がないのが 現状といえる。

本論文は、不特定多数の人間が歩行に供する高低差のある床にお いて、段差と斜路のどちらか一方を選択しなければならない状況下 における選択指針を設定する際のひとつの基礎的知見を負担の観点 から考察した結果を述べるものである。

\section{2. 目的と籍围}

本研究の目的は、同一の高低差をもつ床において 1 段からなる段 差および一定の勾配で連続するひとつの斜路をそれぞれ 1 度、上り、 下りする時、どちらが負担が少ないかを比較検討することにある。
なお、数段で構成される階段や踊り場がある斜路などの場合は本 研究の範囲外とし、今後の課題とする。

ここで、歩行時の負担からみて段差と斜路を比較検討すると研究 方法を設定する理由は、段差や斜路それぞれに関し、負担の大小お よび上り、下り出来るかなどの絶対的評価には身体的健常度などか ら、個人差が非常に大きいと想定されることによる。それ故、本研 究で対象とする歩行者は段差や斜路を自力で歩行でき、かつ杖など の補助具さらには荷物等を持たない状況とし、他の場合は今後の課 題とする。

また、本研究での負担とは、歩行者が、”上りやすい、下りやすい” などと表現する内容を包括するものと定義するが主に生理的負担を 意味する。

さらに、負担は人間の判断によることとする。ここで、人間の判 断によるとしたのは著者らが、段差での負担やキャスターの走行の させやすさ、”゙などの本研究と類似する研究で人間の判断の有効 性を実証していることによる。

なお、段差や斜路での上り、下りにおいて特に問題となるすべり に関しては、すでにその測定、評価方法を提示しているので、4)、5)、 6)、7)すべりからみた安全性は確保されている条件で本研究を進める こととする。

* 東北工業大学工学部建築学科 教授. 工博 


\section{3. 眼往の研究}

負担の観点から、段差と斜路を比較検討した研究例は、著者の検 索の範囲では国内外で見当たらない。一方、段差、階段、斜路それ ぞれについては段差高さ、階段寸法、斜路勾配、などに関しおもに 安全性の観点から国内外で多くの貴重な研究がなされているが、こ れらの研究に関しては、著者らの論文 $11 、 4 ， 8 ， 99$ ，10)に要約検討して いるので本論文では割愛する。

つぎに、本研究に密接なかかわりを持つと考えられる研究成果と して、宇野、古瀬は、住宅階段利用時のエネルギー負担に関し、心 拍数をもとに算出したR.M. R（エネルギー代謝率）を媒体として 実験検討L、R.M. Rは階段寸法に依存せず、昇降時の速度に依存 するという貴重な成果を発表している。11)

さらに、著者らは、段差を下る時の負担を検討し、心理反応（判 断）を基礎的資料として求めた負担と生理的指標である大腿直筋の 管放電量が段差高さを媒体として比例関係にあることを究明してい る。1)

宇野、古瀬の研究 ${ }^{11)}$ から、負担として生理的指標を適用しても 本研究で対象とする 1 回の上り、下りを行う場合の段差と斜路の間

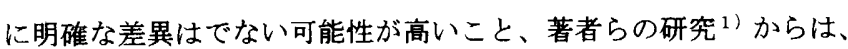
測定などに非常な困難を伴う生理的指標を用いなくとも、人間の判 断をもとに負担を検討することが可能と想定されることから、人間 の判断を基䃈的资料として本研究を遂行することの有効性をあらた めて主張できる。

\section{4. 研究方法の栭夏}

段差と斜路の負担を人間（検查員）の判断を用いる検查（官能検 査）結果により比較検討する本研究では、人間、動作、段差および 斜路に関し、大きくつぎのような前提を設定する。

○検查員は健常な成人男女とする。ここで、実際の場面では、高齢 者などの身体的弱者も重要な対象となるが、研究の遂行において 安全性の確保が困難となるのが明らかに予想できるため、健常な 成人男女の判断を用いることとする。

なお、身体的弱者に近似した状況での判断を得るため、健常者 の身体を拘束することによって肉体の老化を模擬体験する老化模
擬体検装具（以降、老化装具と呼ぶ）12）を装着する場合の検討を 行う。

○動作は、検查員ごとに自由な速度、形態での上り、下りで原則と して各判断ごとに 1 回の動作とする。なお、履物も要因として取 り入れる。

○段差高さおよび斜路の勾配（本研究では斜路長さで表示）はそれ ぞれ、法令を含む実情を包含するものとする。

\section{5. 段差と紏路の負担の比较に関する官能検查}

\section{1 官能検亘手法}

設定する高低差に対応する段差と斜路を原則としてそれぞれ 1 回上 り、下りした時の負担の比較判断から負担比較尺度を構成する官能 検查の概要を表 1 に示す。ここで、負担とは主に生理的観点からの 上り、下りのしやすさの意味であることを検査員に教示することと した。

\section{2 经料}

検查試料となる一対の段差および斜路（以降単に試料と呼ぶ）を 図1、写真 1 のように設計・試作した。

表 1 官能検查の概要

\begin{tabular}{|c|c|}
\hline 構成する尺度負担尺度 & 負担比較尺度 \\
\hline 尺度構成手法 & 比較判断による系列範ちゅう法 \\
\hline $\begin{array}{l}\text { 啠問と } \\
\text { 判断範ちゅう及ひ評点 }\end{array}$ & 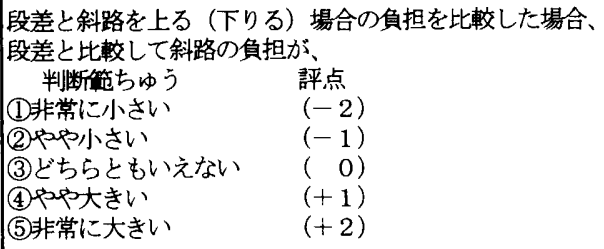 \\
\hline 検査員 & 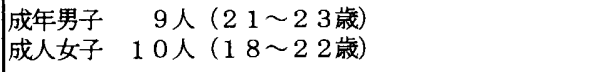 \\
\hline 履物 & $\begin{array}{l}\text { 男子 : 紳士靴・スリッパ・学童シューズ・老化装具 }{ }^{*} \\
\text { 女子 : 中ヒール・スリッパ・学童シューズ・老化装具 }{ }^{*}\end{array}$ \\
\hline 動作 & 普段どおりの上り、下り \\
\hline
\end{tabular}

1. 800
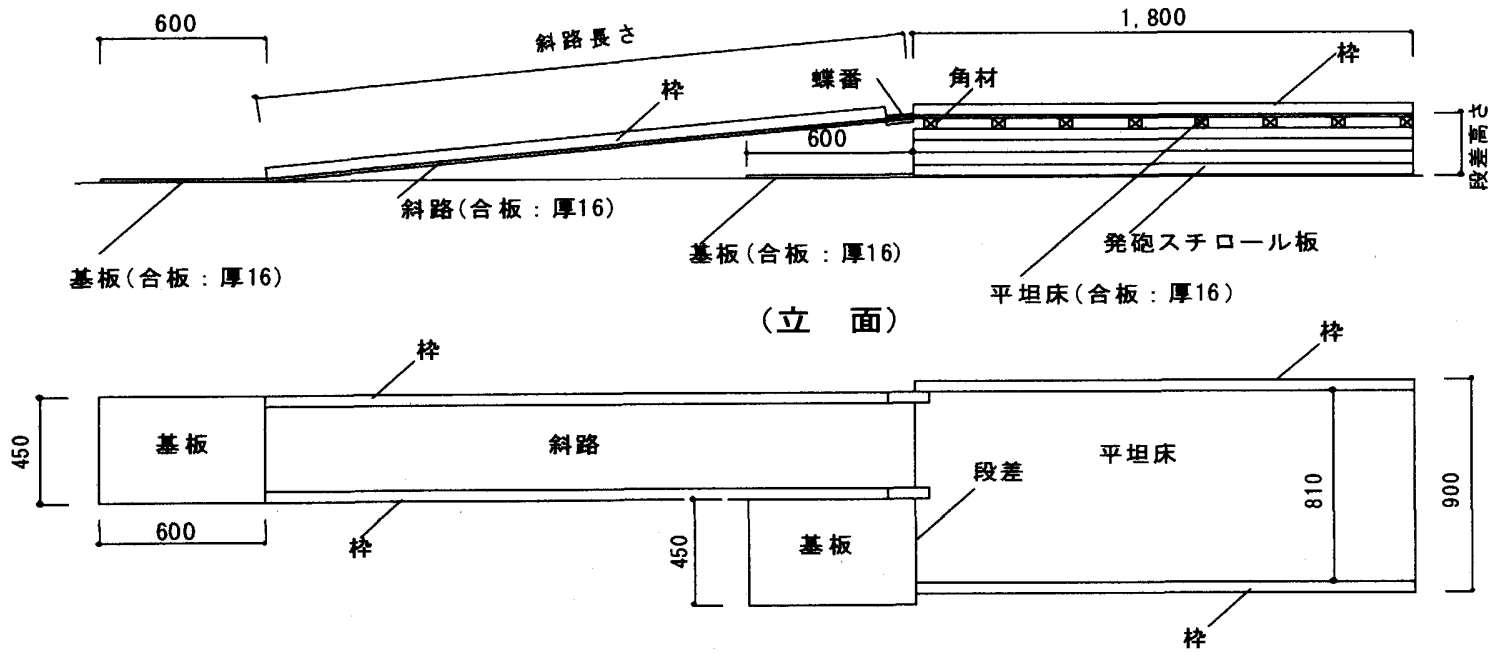

（平 面） 
試料は、段差と斜路を並設したもので、段差は発泡スチロール板 を増堿することにより所定の高さに調節できるようになっている。 斜路は段差高さごとに数段階の長さを設定し、所定の勾配を具現で きるようになっている。

段差高さと斜路長さの組合わせは表 2 の通りで 30 組つまり比較 判断する一対からなる試料数は 30 で、試作後の斜路の勾配の実測 值とともに示している。

表 2 に示した試料の寸法仕様は段差高さおよぶ斜路勾配の法的規 制および実態調查をもとに実情を包含するように設定している。

なお歩行および上り、下りに供する試料表面（合板）のすべり 抵抗（C.S.R'）は著者が開発したすべり試験機（ONO・P P S M）で、0.6 5〜0.75 で本検査を遂行するのにさしさわりのない ことを確認している。13) また、表 2 において段差高さが 20 c m、 $25 \mathrm{~cm}$ で斜路長さが $30 \mathrm{~cm}$ の試料において上り、下りが困難な 場合は、実際の動作を完遂せずに判断してもよいこととした。

また、純粋に負担の比較判断がなされるよう、手摺は設定しない こととした。

試料は温度 $20{ }^{\circ} \mathrm{C} \pm 5{ }^{\circ} \mathrm{C}$ 、湿度 $50 \% \pm 10 \% \mathrm{R} \mathrm{H}$ 、試料面照度 $234 \sim 3791 \times$ の環境条件を保ちかつ本検查を遂行するのに十 分な広さをもつ実験室に設置した。

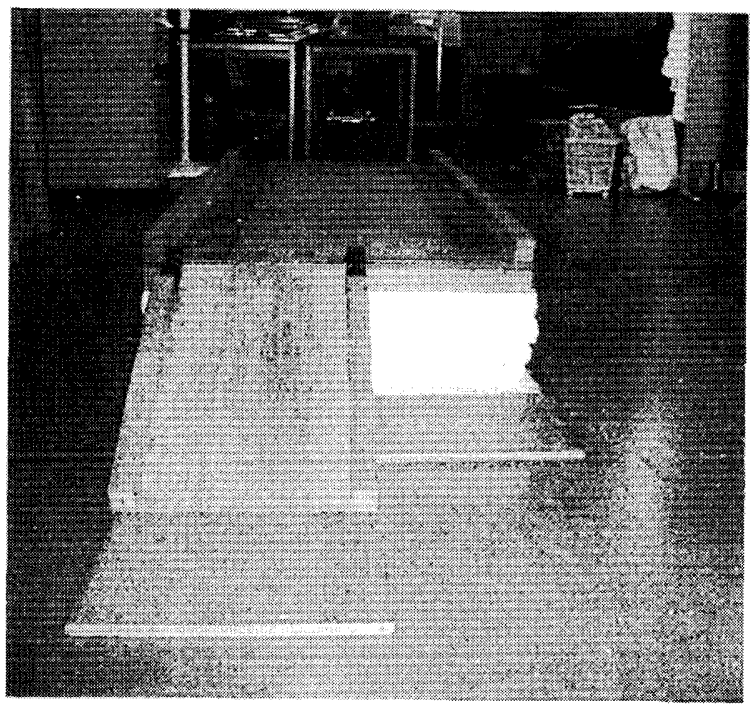

写真 1 試料全景

\section{3 険查員}

負担を比較判断する検查員は 18 才から 23 才の健常な成人男女 で、身体的弱者は、4．述べた理由から選定しないこととした。

\section{4 功作}

動作は開眼で、 $0 \sim 1 ， 2$ 歩の歩行で基板上に立位し、基盤から 段差、斜路各々を上り、下りする極く日常的な動作とした。

なお速度、利き足、段差と斜路での動作順等の規制は判断の自由 度の制約、動作の不自然さの導入に結びつくと考え、行わないこと とした。

\section{5 展物}

日常生活における一般的な履物を選定した。なお、老化装具は、 学童シューズを履いた状態にそれぞれを装着することとした。写真 2 に履物および老化装具を示す。

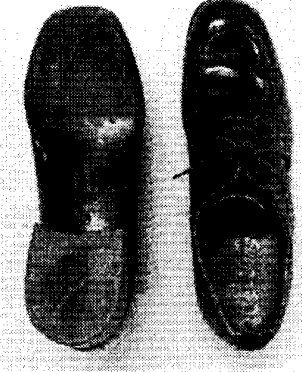

(イ）紳士靴

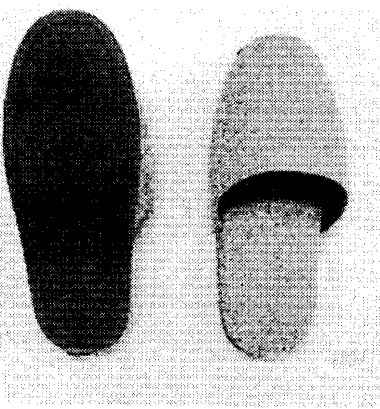

(ハ）スリッパ

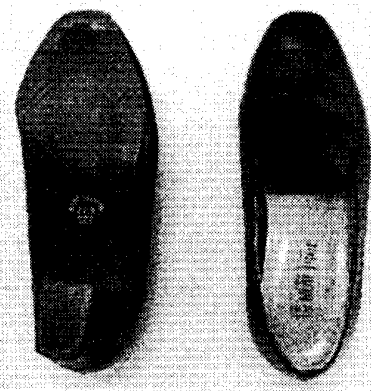

(ロ） 中ヒール

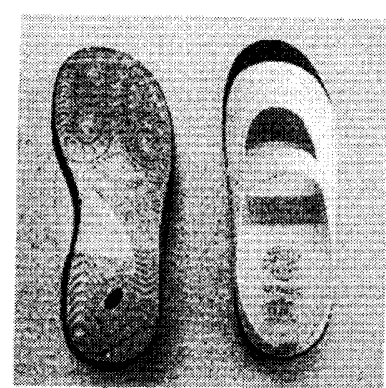

(ニ）学童シューズ

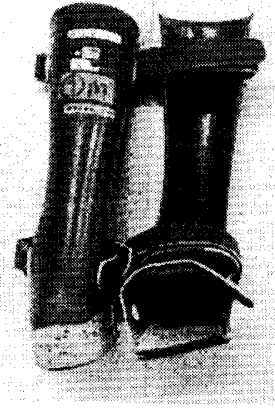

（ホ）老化装具

写真 2 履き物

\section{6 官能検查経過、結果および負担比较尺度の權成}

5. $1 \sim 5.5$ の条件で官能検查を行い基礎資料を得た。具体的 には表 2 に示した 30 組の試料ごとに、段差と斜路のどちらの負担 が小さいかを表 1 に示す判断範ちゅうで返答してもらい基礎資料と した。

表 2 試料の段差高さ、斜路の長さおよび勾配（実測値）の関保

\begin{tabular}{|c|c|c|c|c|c|c|}
\hline & \multicolumn{5}{|c|}{ 段差高さ (cm) } \\
\hline & & 5 & 10 & 15 & 20 & 25 \\
\hline \multirow{6}{*}{ 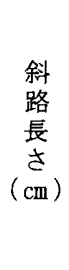 } & 30 & 9.0 & 18.5 & 28.0 & 42.0 & 56.5 \\
\hline & 60 & 5.5 & 10.5 & 15.0 & 21.0 & 25.0 \\
\hline & 90 & 3.5 & 7.0 & 10.0 & 13.0 & 16.0 \\
\hline & 135 & 2.5 & 5.0 & 6.5 & 9.0 & 11.0 \\
\hline & 180 & 2.0 & 3.5 & 5.0 & 7. 0 & 8.0 \\
\hline & 235 & 2.0 & 3.0 & 4.0 & 5.0 & 6.5 \\
\hline
\end{tabular}


なお、段差高さが $20 \mathrm{~cm} 、 25 \mathrm{~cm}$ で斜路長さが $30 \mathrm{~cm}$ の試料の場 合ほとんどの検查員が斜路での動作がしづらいため、完全に上り、 下りの動作をせずに足が触れる程度で瞬間的に非常に動作しづらい （範ちゅう(5)）の判断を下していた。なお、他の組合せの試料の場 合はすべて完全に動作をして判断していた。

検査には検查員 1 名当たり正味約 4 時間必要としたが、疲労によ る判断の乱れが生じないよう、1 日約 2 時間とし、2 日に分けて検 查を実施した。

検查において、検查員から段差や斜路の負担の識別が困難、す心゙ りすぎるあるいはすべらなさすぎる、疲れて判断ができない、など の問題の提起はなく検査を終了した。得られた基礎資料を用いて検 查および構成される負担比較尺度の有効性を検証するため行った分 散分析結果を表 3 に示す。

ここで、性、履物、動作の要因をすべて組合わせると計 78 組と なる。しかし、ここで、性に関し男女で異なるのは履物（紳士靴と 中ヒール) であるが、ヒールの高さが同一で $35 \mathrm{~mm}$ であるので本研 究の観点からはほぼ同一の履物とみなせること、男女を分けて論ず ることに大きな意味はないことから、本論文ではすべての場合につ き男女を一緒にした尺度を使いて考察することとし、尺度の要因の 組合せを 8 組（(性別：1）×（履物：4）×（動作：2））にする こととした。

表には、尺度の要因の全組合わせにつき、それぞれ主勃果(試料)、 個人差の分散比、寄与率を示している。

表 3 から、いずれにおいても主効果の分散比が高度に有意で、検 查が有効であること、個人差の分散比も全て高度に有意であるが、 主効果の寄与率が個人差の場合と比べ非常に大きいことから、構成 される負担比較尺度は個人差を内包するものの十分有効といえる。

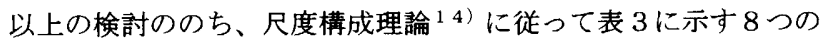
負担比較尺度を構成した。尺度の詳細は紙面の都合上割愛する。

表 3 官能検查の分散分析結果

\begin{tabular}{|c|c|c|c|c|c|c|}
\hline \multirow{2}{*}{$\begin{array}{l}\text { 負担 } \\
\text { 比較 } \\
\text { 尺度 }\end{array}$} & \multirow{2}{*}{ 履物 } & \multirow{2}{*}{ 動 作 } & \multicolumn{2}{|c|}{ 分散 比 } & \multicolumn{2}{|c|}{ 奇与率（\%） } \\
\hline & & & 主勃果 & 個 人差 & 主効 果 & 個人差 \\
\hline 1 & 紳士靴 & 上り & 45.9 & 5.1 & 66.9 & 3.8 \\
\hline 2 & (女) & 下り & 37.4 & 4.2 & 62.7 & 3.4 \\
\hline 3 & & 上り & 45.9 & 5.2 & 66.8 & 3.9 \\
\hline 4 & & 下り & 45.3 & 5.3 & 66.5 & 4.0 \\
\hline 5 & 学童シュー & 上り & 56.4 & 5.9 & 66.6 & 4.5 \\
\hline 6 & (男·女) & 下り & 47.4 & 4.2 & 68.2 & 2.9 \\
\hline 7 & & 上り & 56.9 & 7. 2 & 70.4 & 4.0 \\
\hline 8 & & 下り & 44.7 & 17.4 & 59.4 & 13.8 \\
\hline
\end{tabular}

*主効果 $\mathrm{F}(29,0.01)=1.84$

*個人差 $\mathrm{F}(29,0.01)=0.92$

\section{6. 考察}

6. 1 負担比较尺度の相関について

5. で構成した $8 つ の$ 負担比較尺度に関して、尺度同志の単相関
・係数を算出した結果を表 4 に示す。表から、いずれの負担比較尺度 の組合わせの相関も統計学的には高度に有意となった。

以上より、負担の観点から段差と斜路を比較する場合、履物、動 作により負担の比較が相対的に大きくは異ならないといえる。

表 4 負担比較尺度相互の単相関係数

\begin{tabular}{|c|c|c|c|c|c|c|c|}
\hline 尺度名 & 8 & 7 & 6 & 5 & 4 & 3 & 2 \\
\hline 1 & 0.94 & 0.97 & 0.98 & 0.99 & 0.98 & 0.97 & 0.97 \\
\hline 2 & 0.97 & 0.97 & 0.97 & 0.98 & 0.98 & 0.97 & \\
\hline 3 & 0.97 & 0.97 & 0.98 & 0.98 & 0.98 & & \\
\hline 4 & 0.97 & 0.98 & 0.98 & 0.99 & & & \\
\hline 5 & 0.96 & 0.98 & 0.99 & \multirow{3}{*}{\multicolumn{3}{|c|}{$r(6,0.01)=0.84$}} & \\
\hline 6 & 0.96 & 0.97 & & & & & \\
\hline 7 & 0.96 & & & & & & \\
\hline
\end{tabular}

\section{2 負担からみた、段差高さと料路長さの関保について}

図 2 に負担からみた、段差高さと斜路長さの関倸を示す。 図から、上り、下り、段差高さにかかわらず、斜路長さが大きく なるほど相対的に斜路での負担が小さくなることが明確である。

ここで、注目すべきは、図中」印で示すように段差高さごとに負 担がどちらともいえない（簀ちゅう(3)）斜路長さが存在しており（以 降、等価斜路長さと呼ぶ)、等価斜路長さより長い斜路長さの場合は 斜路の方が負担が小さく、逆に短い場合は段差の方が負担が小さい ことがわかる。つまり負担の観点から床の高低差ごとに段差と斜路 のどちらが適切かを選択する指標を設定できる可能性があることを 示している。

以上の結果を定性的ではあるが、身体脚部の動きに伴う筋活動の 観点から、つぎのように推察できる。

上りの場合、段差、斜路ともに、おもに大腿四頭筋と下腿三頭筋 に収縮、弛緩からなる筋活動が発生するが段差の場合は高さ、斜路 の場合は短かさ（勾配）に比例して筋活動が増大し、笳活動の大小 が負担の大小の反応として提示される。

下りの場合も同様でおもに下腿三頭筋、前脛骨筋の筋活動の大小 が負担の大小の反応として提示されると考えられる。

つまり、段差高さを一定とした場合段差での動作と同程度の筋活 動が必要となる斜路長さが存在することから、範ちゅう(3)該当す る段差高さと斜路の長さの組合わせが、段差高さごとに求め得るこ とになる。

なお、段差での一瞬の筋活動と斜路での連続する筋活動との本質 的な差異、筋活動量の定義などに関しては、本研究の目的を達成す る上で、必要不可久とはいえずかつ述べる知見も持ち合わせていな いので割愛する。

\section{3等価斜路長さについて}

図 3 に図 2 に印で示した等価斜路長さを求めた結果を段差高さ、 動作、履物ごとに示した。

全体として、いずれの場合も段差高さに比例して等価斜路長さが 長くなることがわかる。 

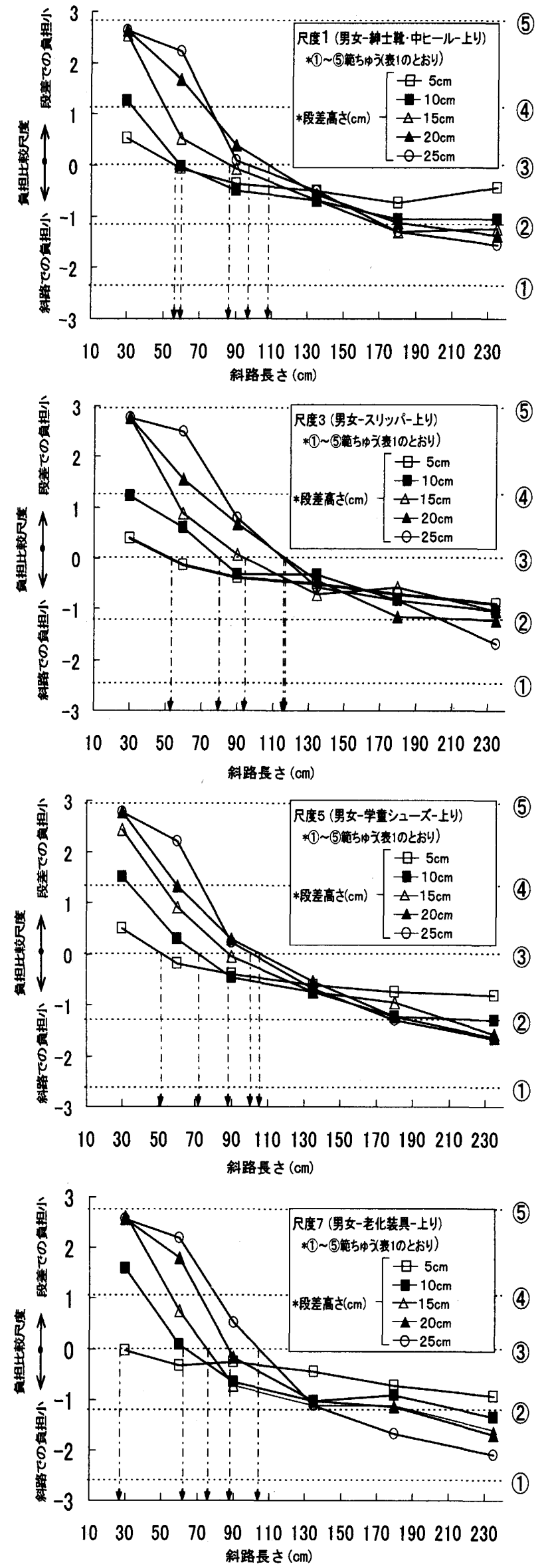
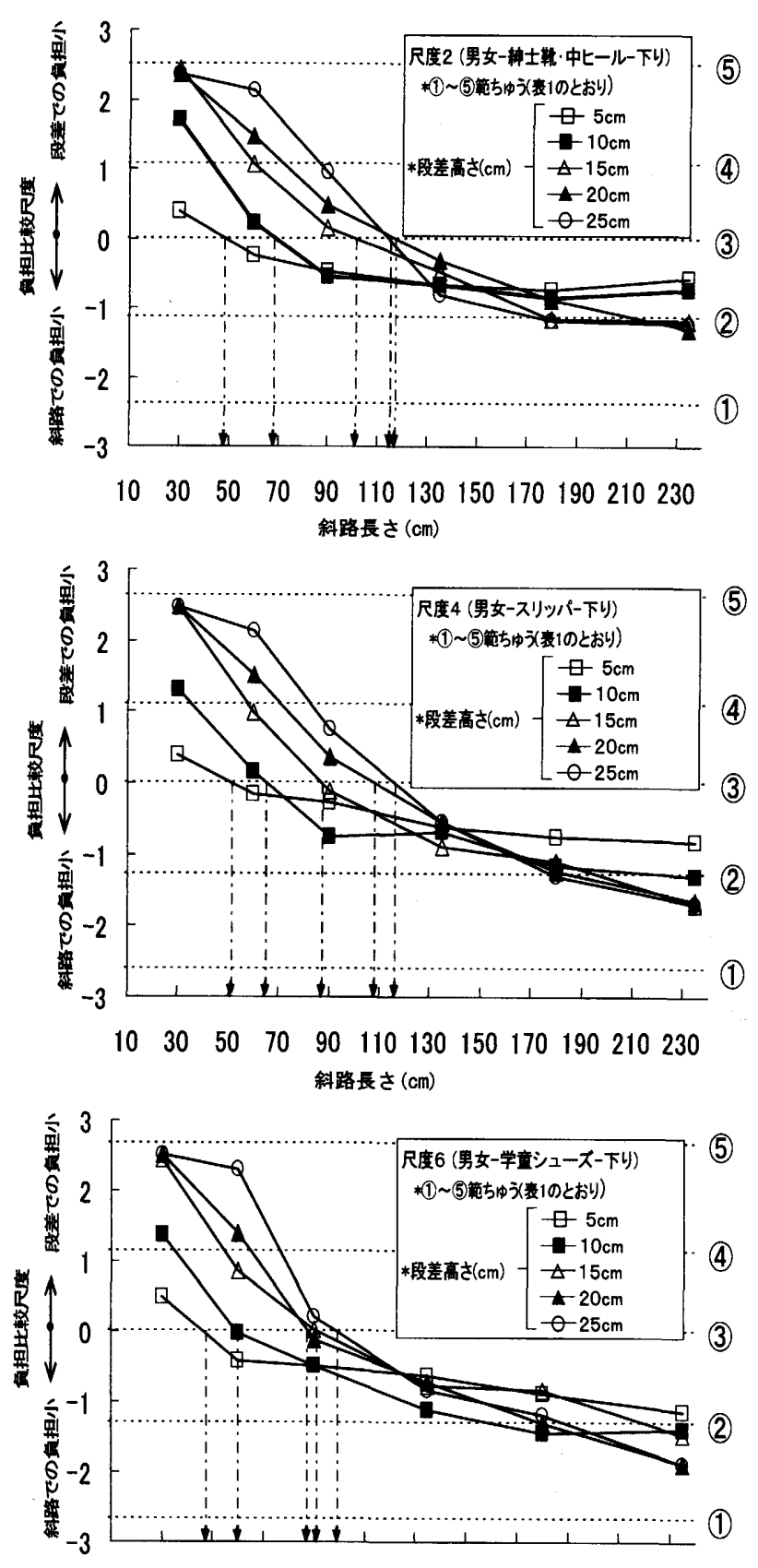

$\begin{array}{llllllllllll}10 & 30 & 50 & 70 & 90 & 110 & 130 & 150 & 170 & 190 & 210 & 230\end{array}$ 斜路長さ $(\mathrm{cm})$

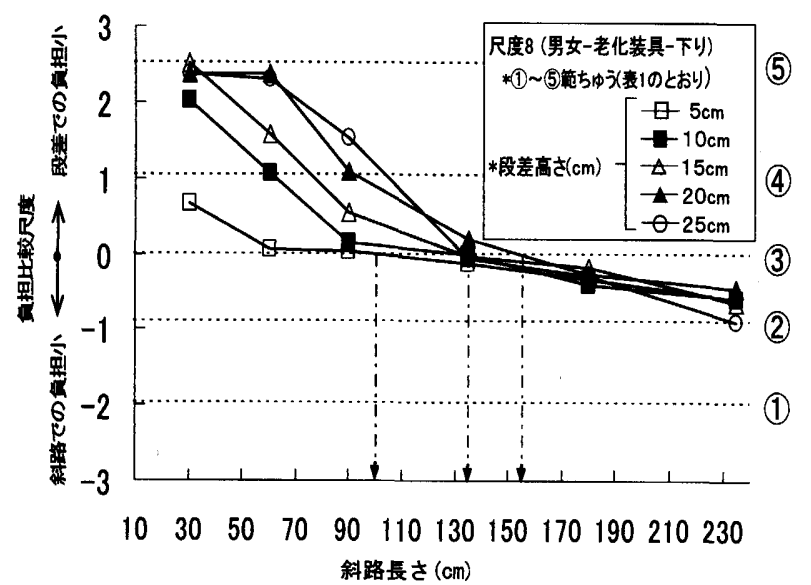

斜路長さ $(\mathrm{cm})$

図 2 段差（高さ）に対する斜路（長さ）の負担（負担比較尺度）の関係 
つまり、段差を上り、下りする負担と等価な負担の斜路にするに は、段差高さに対応した等価斜路長さと等しい長さをもつ斜路にす る必要があるといえる。

さらに、詳細に考察すると、まず、老化装具の場合に顕著な特色 がみられる。

すなわち、他の履物の場合と比較し、同じ段差高さとした場合、 負担が等価な斜路にするには下りの場合に相対的により長い斜路に する必要があること、同様に、上りの場合には相対的により短い斜 路で等価な負担になることがわかる。

このことは、老化装具を装着した状況を高齢者を代表とする身体 的弱者に近似した状況とすれば、身体的弱者の場合、下りの場合は より長いすなわち勾配の小さい斜路にする必要があること、つまり、 前のめり状態になりやすい状況に対して安全性を確保する必要があ ること、上りの場合はもともと前のめりの状況の方が上りやすいと 想定されることから相対的に他と比較して短い斜路つまり勾配の大 きい斜路でもよいことを示していると考える。その他の場合は、上 り、下りに大きな特徴は見られず等価斜路長さも、ほぼ老化装具の 上り、下りの間に布置している。

ここで、図 3 を高低差のある床を上り、下りする場合、段差にす るか、斜路にするかの問に答える指標とする場合、まず、段差高さ、 動作、履物ごとに、等価斜路長さより傾斜長さが長くなれば（図中、 等価斜路長さより右の斜路長さ) 斜路の負担が小さく、かつ図 2 と 合わせれば斜路長さに比例してより負担が小さくなるといえる。逆 に等価斜路長さより斜路長さが短くなれば（図中、等価斜路長さよ り左の斜路長さ）段差の負担が小さくなるといえる。

また、高低差のある床において段差と斜路について、等価斜路長 さを目安にして検討する場合、履物、動作の条件をいかなる場合の 等価斜路長さとするかが大きな問題となるが、少なとも身体的弱者 も利用することを前提とすれば、図 3 に示した老化装具の下りの場 合の值をその目安にする必要があろう。

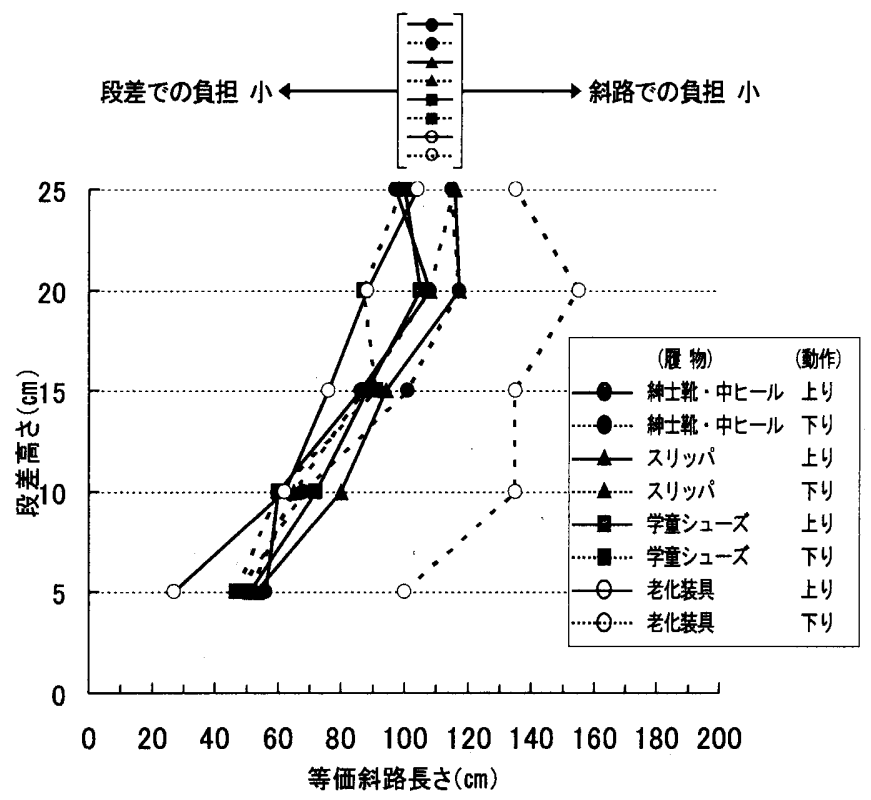

図 3 段差高さと等価斜路長さの関係

\section{7. 結}

高低差のある床を人間が歩行する場合、段差と斜路のどちらが負 担が大きいかに関し、人間の動作的の判断をもとに考察し、設定し た条件の範囲で以下の結論を得た。

- 同一高低差に対し、等価な負担となる、段差高さと斜路長さの組 合せが存在する。本研究ではこの斜路長さを等価斜路長さと定義 した。

・ある段差に対して等価斜路長さより長い斜路にすれば段差と比較 してより負担が小さい斜路になる

・同一高低差に設置する段差と斜路の負担の大小を考察する際の利 用者側の条件は、高齢者等の身体的弱者の下りの場合を中心に検 討することが重要となる

・等価斜路長さの絶対值は、図 3 より求めることができる。 なお、本論文で用いた基碄デー夕は、平成 15 年度東北工業大学 建築学科小野研究室研修生、長崎隆志、三島良太の諸君によるもの である。また、本論文の作成には工藤瑠美君 (東北工業大学大学院)、 劉敏永君（東京工業大学大学院）の協力を得たことを記して謝意を 表する。

\section{素考文䰚}

1) 小野英哲, 三上貴正, 猫本泰彦, 横山裕, 高橋宏椡: 安全性からみた段 差の評価に関寸る研究 降りる時の負担の観点から, 日本建築学会構 造系論文報告東 No. 432, pp. 19〜27，1992.2

2）小野英哲，三上貴正，高橋宏樹，横山裕：非駆動キャスタ一の直進走行 性からみた林の相対的評価方法に関する研究 床のかたさの観点から， 日本建築学会構造系論文報告集 No. 449, pp. 47〜 53，1993.7

3）小野英哲, 和田茂明, 高橋宏樹：車椅子の直進走行性からみた建築物床 および屋外舗装路の相対的評価方法に関する研究 かたさの観点から， 日本建築学会構造系論文集 No. 459, pp. 31 39，1994. 5

4）小野英哲, 須藤拓, 三上贵正 : 安全性からみた階段のすバりの評価方法 に関する基礎的考察 安全性からみた階段のすべりの評価方法に関す る研究（その1），日本建築学会構造系論文報告集 No. $362 ，$ pp. $1 \sim 10$, 1986. 4

5) 小野英哲, 武田清, 永田久雄: 階段各部分のす心゙り抵抗の測定方法 安 全性からみた階段のすべりの評価方法に関する研究 (その2), 日本建 築学会構造系論女報告集 No. 373, pp. 19〜26, 1987.3

6）小野英哲，武田清，三上贵正，大野隆造：安全性からみた階段のすべり の評価方法の提示 安全性からみた階段のす心゙りの評価方法に関する 研究 (その 3 ), 日本建築学会構造系論文報告集 No. 383, pp. 1 7, 1988. 1

7）小野英哲，北山大，高橋宏樹：安全性からみた斜路のすべりの評価方法 に関する研究，日本建築学会構造系論文集 No. 448, pp. $11 \sim 18$, 1993. 6

8）小野英哲 : 横断時の斜路のす心゙りの考察および安全性からみた斜路のす ベりの総括的評価方法の提示, 日本建築学会論文報告集 No. 562 , pp. $21 \sim 26,2002.12$

9）小野英哲：階段の寸法差と安全性の低下に関する基礎的考察，日本建築 学会論文報告集 No. 565 , pp. 33〜 39, 2003.3

10）小野英哲：つまずき、からぶみからみた斜路の勾配に関する考察，日本 建築学会論文報告集 No. 572, pp. 25 29, 2003. 10

11 ）宇野英隆，古瀬敏 : 住宅階段利用時のエネルギー負荷に関する検討， 日 本建築学会論文報告集 No. 345, pp. 115 121，1984. 11

12 ) 川村次郎，溝㴊隆，後藤義明 : 健常者がからだの不自由を体験する装具 (体験装具)，第 7 回 日本義肢装具学会学術大会

13 ）小野英哲 : 携带型床のすべり試験機 (ONO・P P S M) の開発，日本建 築学会構造系論文集 No. 585, pp. $51 \sim 56,2004.11$

$14 ）$ J . P. ギルホード, 秋重義治監訳 : 精神測定法, 倍風館, pp. 276〜 301, 1959 